\title{
Pokkah Boeng: An Emerging Disease of Sugarcane
}

\author{
Vishwakarma SK${ }^{1}$, Kumar $\mathrm{P}^{1,3 *}$, Nigam $\mathrm{A}^{2}$, Singh $\mathrm{A}^{1}$ and Kumar $\mathrm{A}^{1}$
}

${ }^{1}$ UP Council of Sugarcane Research, Shahjhanpur-242001 (U.P.), India

${ }^{2}$ Department of Life Sciences, IGNOU, New Delhi-110068, India

${ }^{3}$ Department of Biotechnology Engineering, Ben Gurion University of the Negev, Beer Sheva-84105, Israel

\begin{abstract}
Sugarcane is one of the most important crops for the sugar production in India and Uttar Pradesh (UP) is the top on sugarcane while second in sugar production. Many biotic and abiotic stresses affected the sugarcane production among the reported diseases of sugarcane; Pokkah boeng is now playing a very important role due to its economic threats in UP. Recent survey during 2007-13 showed increasing trend of disease incidence and most of the commercial cultivars affected by the disease ranged from 1\%-90\%. Although Pokkah boeng comes under minor concern but these days it is going to be major on basis of their rapid epidemiology during last few years. Nowadays, the incidence and severity of Pokkah boeng disease has been reported from major sugarcane growing states like Uttar Pradesh, Maharashtra, Punjab, Haryana, Assam, Tamil Nadu and Bihar in India and other sugarcane growing countries. Keeping in view the seriousness of the problem, the present review summarise the distribution, establish a suitable genetic base and disease management practices through various approaches.
\end{abstract}

Keywords: Fusarium moniliforme; Malformed; Epidemiology; Symptomology; Management

\section{Introduction}

Sugarcane is a cash crop and cultivated in most of the states of India with total area coverage 4.2 M ha [1]. India is the largest consumer of sugar in the world with annual consumption of about 19 million MT (Metric Tons) and the second largest producer of sugar next to Brazil, with production in the sugar year 2009-10 crossing 28 million Mt in India. Uttar Pradesh occupies as premier position of sugarcane cultivation accounting for 42.2 million hectare and $30 \%$ of the area and production respectively. Average cane yield of UP (58.2 MT/ha) is very lower than the national average (66.9 MT/ha). Similar to yield, sugar recovery in UP is also lower (9.51\%) than national average $(10.27 \%)$, respectively due to the several diseases.

Pokkah boeng of sugarcane caused by Fusarium moniliformae and the pathogen was first described by Sheldon [2] and the perfect stage of pathogen is Gibberella fujikuroi (Sawada). Fusarium is now confirmed by several workers as a causal agent of Pokkah Boeng in sugarcane in Asia as well established pathogen by many workers [35]. Pokkah Boeng is the most serious and devastating disease not only in central Uttar Pradesh but also in the whole of the Southern and Northern sugarcane growing zone of India. Pokkah Boeng is a Javanese term denoting a malformation or distorted top was originally in Ja1va but in that time no causal agent was established and its incidence was recorded by Padwick [6]. Pokkah Boeng disease recorded in all over the countries where sugarcane grown and pathogen spreads in windblown rain, infected cane cuttings, pupae and adults of sugarcane stem borers [7-9]. This disease was well-known in sugarcane for long time but severity of disease reported in two commercial varieties Co7219 and Co C671 in Maharashtra 1983-1984 [10]. Fusarium moniliforme var. subglutinans reduce the quality of the harvested crop mainly among varieties with high sugar yields the sugar production depending upon the variety up to $40.8-64.5 \%$ [11].

\section{Symptomology}

The characteristics symptoms of Pokkah Boeng disease are the appearance of chlorotic patches towards the base of the young leaves, in acute cases disease shows distortion of stalk with external and internal cut like lesions and rotting of apical part of stalk. Under field conditions, the disease may develop many variations from the general symptoms, but the final result is usually a malformed or damaged top and stalk. The base of affected leaves is often narrower as compared to normal leaves. Knife cut symptoms of the disease were reported in varieties CoS767, CoC671, CoC8014, Co1158, CoS8315 and CoS 8436 [12]. Development of disease symptom in four phases was observed namely chlorotic phases I and II, top rot and knife cut phase (Figure 1). The apical leaves may also show pronounced wrinkling and twisting depending upon the susceptibility of varieties and existing climatic conditions also malformed or damaged top and stalk due to this disease [13]. The symptoms of Pokkah boeng disease were mainly two types i.e., chlorotic phase and acute phase of top rot [10] and knife cut (fourth phase) of this disease in Maharashtra [12]. Similar findings of about the disease symptom were also reported by workers [14-16].

\section{Epidemiology}

\section{Status of Pokkah Boeng disease}

During the survey of different sugarcane areas of last few years (2007-13), it has been observed that the incidence severity of Pokkah Boeng disease increases and affects almost all the sugarcane cultivars which is recommended for general cultivation for different agro climatic regions. During this year (2012-13), 90\% and 5\%-30\% infection was observed in genotype S. 224/10 and promising variety CoSe 01434 at Sugarcane Research Institute, Shahjahanpur. However, 15\% infection was noticed in variety CoS 07240 at Sugarcane Research Station, Gola

*Corresponding author: Pradeep Kumar, Department of Biotechnology Engineering, Ben Gurion University of the Negev, Beer Sheva-84105, Israel, E-mail: pkbiotech@gmail.com/pradeepgkp17@yahoo.co.in

Received January 30, 2013; Accepted March 21, 2013; Published March 26 , 2013

Citation: Vishwakarma SK, Kumar P, Nigam A, Singh A, Kumar A (2013) Pokkah Boeng: An Emerging Disease of Sugarcane. J Plant Pathol Microb 4: 170 doi:10.4172/2157-7471.1000170

Copyright: (c) 2013 Vishwakarma SK, et al. This is an open-access article distributed under the terms of the Creative Commons Attribution License, which permits unrestricted use, distribution, and reproduction in any medium, provided the original author and source are credited. 


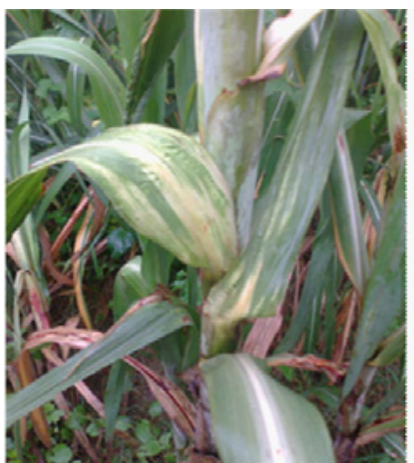

Chlorotic Phase I

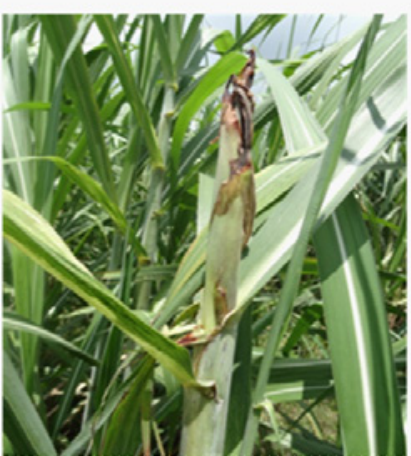

Top Rot Phase

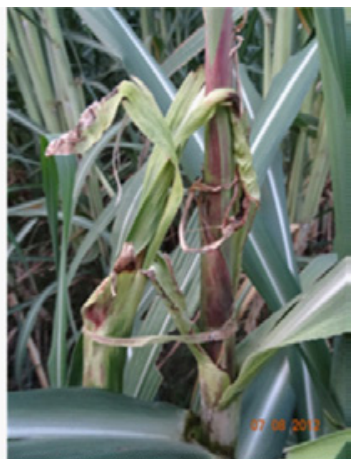

Chlorotic Phase II

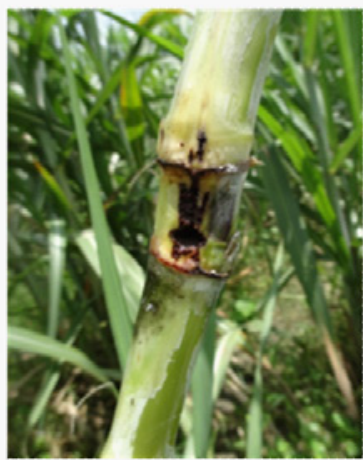

Knife cut Phase
Figure 1: Different stages of pokkah boeng disease.

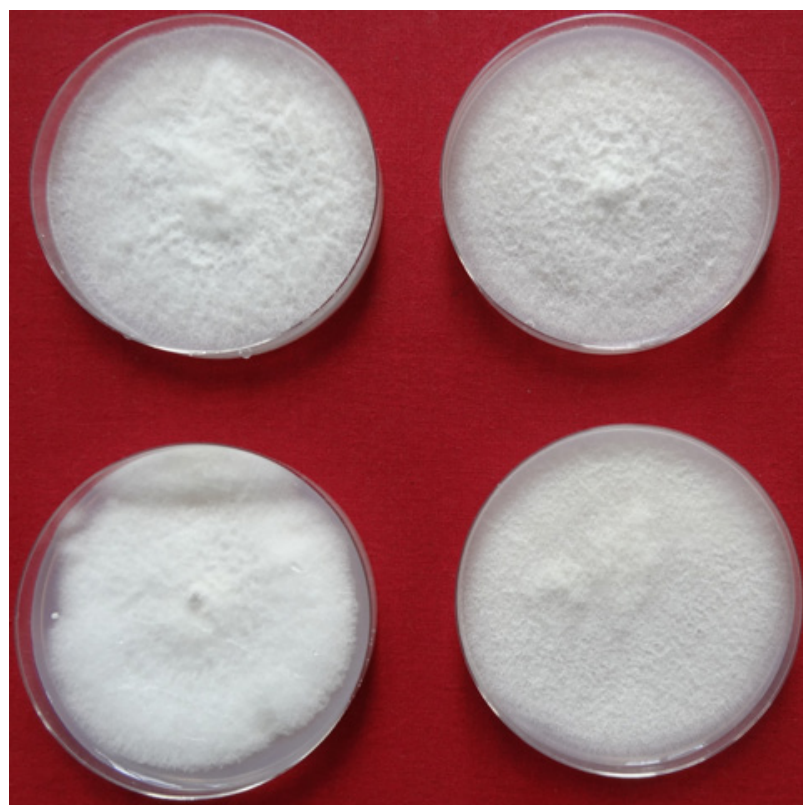

Figure 2: Morphological variability among isolates of Fusarium moniliforme isolated from pokkah boeng disease samples.

(Lakhimpur Kheri). Beside this, it has also been reported from other districts like Bareilly (Baheri), Sitapur and Pilibhit in many sugarcane cultivars viz: $\operatorname{CoS}$ 8436, Co 0238, CoS 97264, CoS 8432, CoS 91269, $\operatorname{CoS} 84212$, CoSe 92423, CoS 98259, CoS 07250 and CoS 07240 in stray to moderate level. Knife-cut stage of Pokkah Boeng was also observed in CoS 07240, Colk 9709, CoS 09231, S. 4386/07 and S.3438 from Gola, Baheri and Shahjahanpur respectively. In Western Uttar Pradesh (Saharanpur, Muzzafarnagar, Bijnour, Khatauli, Mawana, Shimbhawali, Titawi, Seohara districts), the disease were observed in varieties CoS 8436, CoS88230, CoS94257, CoS767, CoS94270, CoSe95422, CoSe98231 and CoJ64 with stray to moderate level and in Eastern Uttar Pradesh (Gonda, Baharaich and Kushinagar districts), the disease were noticed in varieties CoS91269, Co0238 and CoSe01434 in trace to moderate level. Knife-cut stage was observed in varieties CoS91269 from Maizapur sugar factory zone of Bahraich district in traces (Table $1)$.

According to the disease scenario of different states of India viz. Assam, Andhra Pradesh, Tamil Nadu, Uttar Pradesh, Bihar, Haryana, Maharashtra, it was observed that the incidence of Pokkah Boeng disease were found in trace to moderate level on most of commercial varieties but the incidence severity is high in Uttar Pradesh and Maharashtra rather than other states and these two are major sugarcane growing states of India. Symptoms of the diseases have been observed in many varieties of Andhra Pradesh (Co7805, CoA 99082, CoV94102, 98V95 \& 2000V59) and Haryana (CoH151, CoJ85 \& CoS8436). Top rot symptom of the disease was noticed in Haryana (CoS8436, CoH152, CoH133, Co89003 and CoH136) and Punjab (CoJ 854). In Maharashtra, amongst the foliar diseases, Pokkah Boeng disease is becoming a major threat to sugarcane and incidence were observed in many varieties (CoV19805, Co 05002, CoM 08090, Co 8014, Co 94012 , VS 1434, CoC 671, Co 7527, Co 86032). In Bihar, trace to moderate levels of Pokkah Boeng disease was observed in many varieties.

Disease were reported from different other country after the first report of disease from java in 1896 by walker and went and studied by several workers [13]. From Malaysia, the disease was recorded in 1973 and it concluded that the disease incidence occur when crops are grown in a climate where hot and dry season persists followed by a wet season that was helpful for the spread of Pokkah Boeng [17]. Disease started when plants aged 3-7 months older, then plant growing very rapidly than the older crop [18]. Giatgong [19] from Thailand reported F. moniliforme Sheldon and G. fujikuroi (Saw) Wr. were the causal agents of Pokkah Boeng. Several Fusarium species were isolated from the Pokkah Boeng affected tissue of sugarcane in Indonesia i.e., $F$. anguioides Sherb. F. bulbigenum Cke. and Mass. var. tracheiphilum (E. Sm.) Wr., F. moniliforme Sheld., F. moniliforme Sheld. var. subglutinans Wr. and Rkg. [Gibberella fujikuroi (Saw.) Ito ap. Ito and Kamura], F. moniliforme Sheld. var. anthophilum (A. Br.) Wr., F. neoceras Wr. and Rkg., F. orthoceras App. and Wr. var. longius Wr. and F. semitectum B. and Rav [20]. Fusarium andiyazi and F. Sacchari play important role in the development of pookah boeng disease and prove the association of F. andiyazi with sugarcane pokkah boeng in vitro from South Africa [4]. Pokkah Boeng of sugarcane also reported from Iran by $F$. verticillioides. Morphological characteristics, pathogenecity test on healthy sugarcane and VCG's for correctly identification of Fusarium species causing Pokkah Boeng; and also reported the genetic diversity among the $F$. verticillioides in sugarcane fields using the vegetative compatibility group technique $[5,21]$.

\section{Characteristics of pathogen}

Fusarium moniliforme showed different colour for its mycilium pale white, pink and purple mycilium and for pigmentation of metabolites also during the growth on artificial medium and its conidial growth is affected by glucose concentration (Figure 2) [22,23]. Morphological study of Fusarium spp. by earlier worker on Potato Dextrose Agar 
Citation: Vishwakarma SK, Kumar P, Nigam A, Singh A, Kumar A (2013) Pokkah Boeng: An Emerging Disease of Sugarcane. J Plant Pathol Microb 4: 170 doi:10.4172/2157-7471.1000170

Page 3 of 5

\begin{tabular}{|c|c|c|c|c|}
\hline Year & Area surveyed & Varieties affected & $\begin{array}{l}\text { No. of affected varieties/ } \\
\text { genotypes }\end{array}$ & $\begin{array}{c}\text { Incidence } \% \\
\text { range }\end{array}$ \\
\hline \multirow[t]{3}{*}{$2012-13$} & \multirow[t]{3}{*}{$\begin{array}{l}\text { Shahjahanpur, Baheri, Gola, Ajbapur, } \\
\text { Seorahi, Gonda, Baharaich, } \\
\text { Kushinagar, Pilibhit }\end{array}$} & $\begin{array}{l}\text { CoS07250, Co0238, CoS 97261, CoS98231, CoS8436, CoS97264, } \\
\text { CoS88230, CoS98259, CoS05125, CoS 91269, Co0238, CoS 01434, } \\
\text { Co0239 }\end{array}$ & 13 & $1-15$ \\
\hline & & CoSe01434 (SRI, Shahjahanpur Farm) & 01 & 25 \\
\hline & & S. 224 (SRI, Shahjahanpur) & 01 & 90 \\
\hline 2011-12 & $\begin{array}{l}\text { Shahjahanpur, Balrampur,Ghazipur, } \\
\text { Gola,Sultanpur }\end{array}$ & $\begin{array}{l}\text { CoSe01224, CoS05452, CoS06455, CoS06456, CoS05434, } \\
\text { CoSe92423, CoSe01235, CoSe96436, CoS8436, CoS07250, } \\
\text { CoS96275, CoS8432, CoS99259, }\end{array}$ & 13 & Stray \\
\hline 2010-11 & $\begin{array}{l}\text { Seohara,Neoli, Tilhar,Gola,Baheri, } \\
\text { Hargaon, Pallia, Rudrabilaspur }\end{array}$ & $\begin{array}{l}\text { CoS8436, CoS767, CoS8432, CoS88230, CoS97261, CoS98259, } \\
\text { CoSe95422, CoSe01424, CoSe92423 }\end{array}$ & 09 & Stray to $5 \%$ \\
\hline 2009-10 & $\begin{array}{l}\text { Shahjahanpur, Bareilly, Hardoi, Sitapur, } \\
\text { Lakhimpur. }\end{array}$ & CoJ84, CoS8436, CoS88230, CoSe98231. & 04 & Traces \\
\hline 2008-09 & Shahjahanpur, Hardoi, Muzzafarnagar. & CoS8436, CoS88230, CoS8432 & 03 & $5-25$ \\
\hline 2007-08 & $\begin{array}{l}\text { Sharanpur,Bijnour, Sitapur,Sultanpur, } \\
\text { Lakhimpur. }\end{array}$ & CoS8436, CoS88230, CoS8432, CoS97261, CoSe95422, CoSe98231. & 06 & Traces \\
\hline 2006-07 & Neoli,Semikhera Gola & CoS8436, CoS8432, CoS88230, CoS97261 & 04 & $1.0-3.0$ \\
\hline 2005-06 & Roza,Rupapur,Pallia, Seohara & CoJ64, CoS8436, CoS8432, CoS88230, CoSe95422 & 05 & $1.0-8.0$ \\
\hline 2004-05 & Neoli,Tilhar,Biswan & CoS8432, CoS94257, CoS94270, CoSe92423, CoLk8102 & 09 & $0.5-3.0$ \\
\hline 2003-04 & $\begin{array}{l}\text { Khatauli,Mawana, Shahjahanpur, } \\
\text { Shimbhawli, Titawi,Gola }\end{array}$ & CoS88230, CoS8432 CoJ64, CoS767 & 04 & $2-10$ \\
\hline
\end{tabular}

Table 1: Incidence status of Pokkah Boeng disease during last ten years in Uttar Pradesh (Source: Annual reports of UPCSR, Shahjahanpur).

\begin{tabular}{|l|c|c|c|c|c|c|c|}
\hline \multicolumn{9}{|c|}{ Meteorological observations during the year 2012} \\
\hline Months & $\begin{array}{c}\text { Rainfall } \\
\text { (mm) }\end{array}$ & \multicolumn{2}{|c|}{ Relative humidity } & \multicolumn{2}{|c|}{ Temperature $\left.\mathbf{~}^{\circ} \mathbf{C}\right)$} \\
\hline & $\mathbf{8 . 3 0}$ A.M. & $\mathbf{5 . 3 0}$ P.M. & Ave. & Max. & Min. & Ave. \\
\hline January & 36.8 & 87.0 & 64.0 & 76 & 17.5 & 6.2 & 11.8 \\
\hline February & Nil & 80.0 & 45.0 & 63 & 23.1 & 9.4 & 16.2 \\
\hline March & Nil & 70.0 & 35.0 & 52 & 30.4 & 13.7 & 22.0 \\
\hline April & 6.2 & 58.2 & 29.2 & 43.7 & 36.6 & 19.9 & 28.2 \\
\hline May & Nil & 41.0 & 23.0 & 32.0 & 40.0 & 24.4 & 32.2 \\
\hline June & 3.4 & 47.0 & 31.0 & 55.0 & 41.1 & 28.1 & 34.6 \\
\hline July & 332.3 & 83.0 & 75.0 & 79.0 & 33.7 & 26.5 & 30.1 \\
\hline August & 479.0 & 89.0 & 82.0 & 85.5 & 32.4 & 26.0 & 29.2 \\
\hline September & 249.6 & 89.0 & 71.0 & 80.0 & 33.4 & 25.2 & 29.3 \\
\hline October & Nil & 82.0 & 50.0 & 66.0 & 32.0 & 17.6 & 24.8 \\
\hline November & Nil & 82.0 & 62.0 & 72.0 & 27.5 & 11.9 & 19.7 \\
\hline December & 2.6 & 89.0 & 67.0 & 78.0 & 23.1 & 8.9 & 16.0 \\
\hline
\end{tabular}

Source : Division of Plant Physiology, Sugarcane Research Institute, Shahjahanpur, U.P.

Table 2: Metrological observations during the year 2012

medium (PDA) and the growth of conidia range from 9.3-29.7 $\mu \mathrm{M}$ in length and 2.7-6.0 $\mu \mathrm{M}$ in width; mycelium width of ranged in between 1.75-7.00 $\mu \mathrm{M}$ [24]. Mycelium of F. moniliforme was generally dense in delicately floccose to felted with powdery appearance due to formation of macro conidia (Figure 3). Many workers reported that F. sacchari as causal agent for Pokkah Boeng in sorghum and also cause the same in sugarcane belongs to the Section Liseola $[8,25,26]$. In India, $F$. sacchari from sugarcane was first described as Cephalosporium sacchari by Butler and Khan [27]. Later F. moniliforme and C. sacchari are separate as distinct organism based on their enzymes and pathogencity characteristics $[12,28]$. Different media had profound influence on the cultural growth characters while the modified Czapeks dox agar was selective medium for $F$. moniliforme and malt extract medium is suitable for the growth [29-31]. On PDA, virulent strains F. moniliforme grew faster than the non-virulent strains and growth is influenced by the nitrogen sources magnesium nitrite followed by sodium nitrate, iron also enhanced the growth and sporulation [32-34]. However Patil and Hapase [10] reported that starch, xylose, fructose, sucrose, glucose and maltose as good carbon source and urea for nitrogen.

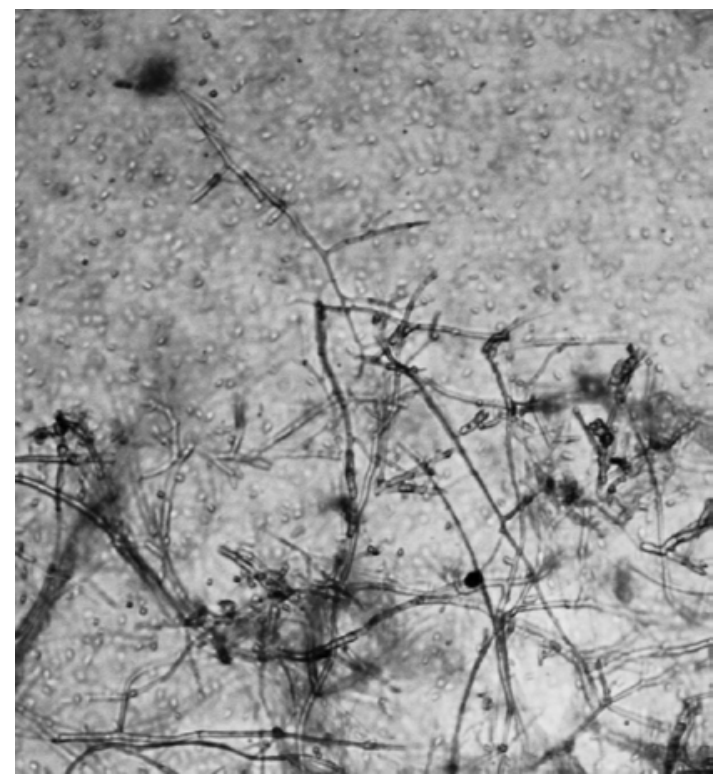

Figure 3: Mycelium and spores of Fusarium moniliforme isolated from pokkah boeng.

Major and minor (N, P, K, S. Zn, Fe, Cu and $\mathrm{Mg}$ ) study of the sugarcane plant affected by the Pokkah Boeng showed the decreasing pattern in stalks and leaves of diseased plant as compared to healthy ones and its incidence have been noticed on broad leaves varieties of sugarcane during monsoon. This may lead to the reduction in weight of cane, length of internodes, juice percent, girth, pol percent and total sugars in juice in infected canes of varieties $\operatorname{CoS} 8436$ and $\operatorname{CoS} 88230$ [3].

\section{Pathogenesis}

The pathogen enters into the host tissues through any injury by insects/borers or natural growth cracks, etc. After the entry of pathogen, the infection thread develops normal hypha which grows within the 
host tissues for some time and then emerges out through the cells to the outer surface and develops acervuli. Rains and heavy dews usually wash the acervuli developed on nodes and internodes and the spores get lodged around the nodes behind the leaf sheath. The spores germinate and the mycelium gets established in bud scales, root primordial or leaf scars and later within the plant tissues. Electron microscopic of infected leaves revealed that after lodging of conidia and incubation of minimum one month at the time of germination, the thin walled bulliform cells of the epidermis are attacked and soon collapse then the older cells of the epidermis are attacked [12]. From the epidermal cells, the hyphae enter the underlying tissues. Changes in the structure of stomata were also observed in the infected leaves but there was no evidence found for the entry of pathogen through stomata.

\section{Host range}

Fusarium moniliforme associated with a wide range of hosts such as banana [35], corn [12], cotton [31], mango [36], sugarcane and other important crops [37]. The F. moniliforme causes the disease in maize, sorghum, rice and sugarcane, and produce different mycotoxins (fumonisins, moniliformin and beauvericin). It was reported from Gramineae family along with 31 other families of plants [38]. The Pokkah Boeng pathogen also attacks sorghum and had been reported that the disease was caused by F. moniliforme (Gibberella fujikuroi) [5]. Fungus infects a wide range of species including monocotyledons and dicotyledons causing various diseases such as seedling blight, scorch, stalk and root rot, abnormal stunting or hypertrophy. Pokkah Boeng disease of sugarcane has associated with several diseases of sugarcane such as sett rot, root rot [39], wilt [40,41] and knife cut [42,43].

\section{Transmission and viability of pathogen}

Basically it is an air-borne disease and primarily transmitted through the air-circulation and secondary infection takes place through the infected setts, irrigation water, splashed rains and soil. The pathogen (F. Moniliforme) can survive for 12 months in the plant debris under natural conditions and can remain viable for more than 10 months under laboratory conditions (http://www.vsisugar.com/india/ agriculture_divisions/plantpathology/pokkaboengdisease-sugarcane. $\mathrm{htm}$ ). Fungus could not grow at $50^{\circ} \mathrm{C}$ but it remained viable for at least six months. It is also reported that the survival of a F. moniliforme can observed for 12 months, although incidence is noticed low after nine months. Under natural conditions, maximum survival occurred more than 11 months at $30 \mathrm{~cm}$ in soil. Cool and dry conditions favoured the survival of a fungus in plant debris [43]. Disease may also spread from seeds contaminated with the fungus [11]. Pokkah Boeng pathogen is transmitted by spore movement from one locality to another by air currents and will colonised on leaves, flowers and stems of the plants [44]. Dispersal of spores depends on the environmental condition (windy day, rainy day or dry day) that require different strategies to disperse. Two mechanisms describe by Deacon [45] for the dispersal of the fungal spores: i) Fungus that disperse by rainsplace are based on the "puff" and "tap" mechanism that will cause the dry spore become airborne and usually the spores are curved like Fusarium species. ii) Fungi that grow on leaf surfaces and produces chains of spore can be removed by wind, by mist-laden air or by hygroscopic (drying) movements that cause spore to buckle. Hot and dry weather will lead to the opening of leaves between partially unfolded leaves that provide an opportunity for airborne conidia to settle on the leaves [45]. When the rains start, the conidia are washed down to the susceptible parts of the spindles along the margin of a partially unfolded leaves where they germinate. The conidia germinate and the mycelium can pass through the soft cuticle of young leaves to the inner tissues because the epidermis tissues are still fragile and not protected by the plant system [46]. The mycelium spreads to vascular bundles of the immature stem and blocks the vessels that eventually leads to growth distortions and rupture and the development shows the ladder-like lesions [47]. Bourne [48] reported that the pupae and adults of sugarcane stem borers also can spread the fungus. The top borer known as Chilo spp. often results in a distortion and shortening of the leaves which is similar to that caused by Pokkah Boeng disease [46].

\section{Effect of environmental factors}

Temperature is an important natural factor governing the distribution of a pathogen and it grows and sporulates luxuriantly in a temperature range of $20-30^{\circ} \mathrm{C}$ in both in-vitro and in-vivo condition. Minimum, optimum and maximum temperature for growth of pathogen are $10-15^{\circ} \mathrm{C}, 30^{\circ} \mathrm{C}$ and $35-40^{\circ} \mathrm{C}$, respectively. The severe incidence of the disease occurred in the range of temperature between $20^{\circ} \mathrm{C}-32^{\circ} \mathrm{C}$ with high humidity up to $70-80 \%$ and cloudy weather in rainy season from July to September. We also found the incidence of the disease in month of July to September when humidity range from $79.0-85.5$, temperature ranging $29.0-30^{\circ} \mathrm{C}$ and rain fall is high (Table 2). Temperature ranging from $20-30^{\circ} \mathrm{C}$ and humidity ranging from $75-$ $85 \%$ is the best suitable for the growth of Fusarium pathogen [36].

\section{Control management}

Spraying of different fungicides like Bavistin ( $1 \mathrm{gm} / \mathrm{lit}$. of water) or Blitox (0.2\%) or Copper oxychloride or $0.3 \%$ Dithane M-45 (3 gm/L of water) are the effective for reducing the Pokkah Boeng disease [43]. Two to three sprayings with an interval of 15 days interval reduces the multiplication of a pathogen and losses in yield and quality of cane and therefore, paired row or wider spacing planting of sugarcane is necessary to facilitate the plant protection operations. Canes showing 'top rot' or 'knife cut' should be rouged out from the fields as they are shown. Planting of healthy seed material/use of resistant verities and follow of Integrated Disease Management practices are the best way to prevent disease incidence [49]. F. moniliforme can be disseminated horizontally by airborne spores or crop debris and vertically through the seed pieces. So it is important to uses of resistant varieties and fungicide applications. Both the processes for controlling, is limited and there is increasing need for novel and environmentally sound strategies to control this and other diseases of sugarcane. Burkholderia isolates from sugarcane plants is a crucial step toward further development of these isolates for biological control of Pokkah Boeng and other sugarcane diseases. The endophytic bacteria community associated with sugarcane harbours multiple genera with potential for plant growth promotion and disease control [50].

\section{Acknowledgement}

First author is grateful to Dr. G.P. Rao, Principal Scientist, Division of Plant Pathology, IARI, New Delhi for their valuable suggestions and Dr. Ram Ji Lal, Principal Scientist, Crop Protection Division, IISR, Lucknow for providing literature to compile manuscript.

\section{References}

1. FAOSTAT (2010) FAO statistical data bases

2. Sheldon JL (1904) A corn mold (Fusarium moniliforme sp). New Agr Exp Sta Ann Report 17: 23-32.

3. Singh A, Chauhan SS, Singh A, Singh SB (2006) Deterioration in sugarcane due to pokkah boeng disease. Sugar Tech 8: 187-190.

4. Govender P, McFarlane SA, Rutherford RS (2010) Fusarium species causing pokkah boeng and their effect on Eldana saccharina walker (lepidoptera: pyralidae). Proc S Afr Sug Technol Ass 83: 267-270. 
5. Mohammadi A, Nejad RF, Mofrad NN (2012) Fusarium verticillioides from sugarcane, vegetative compatibility groups and pathogenicity. Plant Protect Sci 48: 80-84.

6. Padwick CW (1940) Soc Rept Ind Agril Res Inst, New Delhi 198-39: 103-115

7. Martin JP, Hawaiian Sugar Planters' Association (1938) Sugarcane diseases in Hawaii. Advertiser Publishing Company.

8. Leslie JF, Summerell BA (2006) The Fusarium Laboratory Manual. Blackwell Publishing, USA.

9. Whittle PJL, Irawan (2000) Pokkah boeng: A Guide to Sugarcane Diseases. Rott P, Bailey RA, Comstock JC, Croft BJ, Saumtally AS, (eds.). CIRAD/ISSCT, Montpellier 136-140.

10. Patil AS, Hapase DG (1987) Studies on Pokkah boeng disease in Maharashtra. Ind Phytopath 40: 290

11. Duttamajumder SK (2004) bacterial diseases of sugarcane in india: a bird's eye view. In: Sugarcane pathology: bacterial and nematodes diseases, Rao GP, Saumtally AS, Rott P, (eds). Science Publishers 15-50.

12. Patil AS (1995) Studies on Pokkah boeng and pine apple disease of sugarcane in Maharashtra with their economic losses in yield and quality of sugarcane. Final Project Report, ICAR, VSI, Pune.

13. Martin JP, Hong HL, Wismar CA (1961) Pokkah boeng. Pages 247-257 in Sugar-cane diseases of the world. Vol. 1, Elsevier Publ. Co. New York 542

14. Han Lioe H (1956) Fusarium-Pokkah boeng resistance trial. Proc Int Soc Sugar Cane Techno 9: 1023-1029.

15. Eira AFDA, Carvalto PCT, Sangiono DE (1974) Studies on aggressiveness of Fusarium moniforme sheld. causal agent of Pokkah boeng in sugarcane. Proceeding ISSCT 15: 374-383.

16. Higgy AH, Abd-Elrazic EA, Rushdi MH (1977) Occurrence of Pokkah boeng disease in Egypt. Proceeding of ISSCT 16: 473-481.

17. Siti Nordahliawate MS, Nur Ain Izzati MZ, Azmi AR, Salleh B (2008) Distribution, morphological characterization and pathogenicity of Fusarium sacchar associated with pokkah boeng disease of sugarcane in Peninsula Malaysia. Pertanika Journal of Tropical Agricultural Science 31: 279-286

18. Raid RN, Lentini RS (2002) Sugarcane Red-rot Disease. Sugarcane Handbook UF/IFAS Publication SS-AGR-206, Florida.

19. Giatgong P (1980) Host index of plant diseases in Thailand. (2ndedn), Dept. of Agriculture, Ministry of Agriculture and Cooperatives, Bangkok, Thailand.

20. Semangun H (1992) Host index of plant diseases in Indonesia. Yogyakarta: Gadjah Mada University Press.

21. Taherkhani K, Alizadeh A, Farokhinejad R, Sharifitehrani A (1998) Identification of causal agents of sugarcane Fusarium diseases in Khuzestan Province. In: Proceedings of $13^{\text {th }}$ Iranian Plant Protection Congress, Karaj, Iran.

22. Bourne BA (1953) Studies on the dissemination of sugarcane disease. The Sugar Journal 16: 19

23. Khanna KL, Rafay SA (1953) Annual report of the scheme for the investigation and control of wilt disease of sugarcane for year ending $31^{\text {st }} 1953$. Cent. Sugarcane Research, Pusa, 1-12.

24. Chatopadhyay BB, Gupta PK (1967) Studies on wilt diseases of pulses. I. Variation in Taxonomy of Fusarium Spp. associated with disease of pulses. Ind J Mycol Res 5: 45-47.

25. Egan BT, Magarey RC, Croft BJ (1997) Sugarcane. In: Soilborne Diseases of Tropical Crops, Hillocks R, Walker JM, (eds.). CAB International, Wallingford 277-302.

26. Nirenberg HI, O'Donnell K (1998) New Fusarium species and combinations within the Gibberella fujikuroi species complex. Mycologia 90: 434-458.

27. Butler EJ, Khan AH (1913) Some new sugarcane diseases. In: Mem Dept Agr India Bot Ser 6: 181-208.

28. Singh RK (1958) Comparative study of Fusarium moniliforme sheld and Cephalosporium sacchari Butler. Science and Culture 24: 135-137

29. Shaikh MM (1974) Studies on wilt of gram caused by Fusarium oxyporum of Cicero in Marathwada region. (M.Sc. Agriculture Thesis).
30. Agrawal VM, Singh CV (1974) Routine testing of crop seeds for Fusarium moniliforme with a selective medium. Seed Research 21: 19-22.

31. Arshad M, Dogar MA, Khan MA, Sahi ST (1992) Physiological studies on Fusarium moniliforme sheld, a boll rotting fungus on cotton. Pak J Phytopatho 2: $1-7$

32. Shahab AF, Fahim MM, Osman AR, Abad Ell-Kader MM (1987) In-vitro studies of Fusarium oxysporum sps. Lupini Minufiya. J Agri Res 7: 41-52.

33. Ali SS, Sonar ML (1984) Influence of iron on the extra cellular amino acid by Fusarium moniliforme Sheld. J Indian Botany 63: 148-150.

34. Agrawal DK, Sharabhoy AK (1978) Physiological studies on the species of Fusarium pathogenic to Soybean. Ind Phytopathol 31: 24-31.

35. Wang BS, Liu CZ, Qi PK (1991) Study on the Fusarium crown rot banana. Acta Phytopath Sinica 8: 133-137

36. Kumar P, Misra AK, Srivastava AK, Modi DR (2011) Mapping of $F$. moniliforme var. subglutinans from normal and malformed panicles and malformed seedlings of mango by recovery method. Plant Archives 11: 567-569.

37. Rao GP, Singh M, Singh HN (1990) Alternative host of sugarcane diseases Sugarcane 8-26.

38. Booth C (1971) The Genus Fusarium. Commonwealth Agricultural Bureau, Bucks.

39. Verma KP, Singh MP, Upadhyay UC, Singh HN (1984) Knife cut, the first report of the incidence of this disease in India. Sugarcane 40: 817-820.

40. Saponaro A (1980) Observation of some cases of maize stalk and root rot due to Fusarium. Annals of the Experimental Institute for Plant Pathology 6: 5-14.

41. Waraitch KS, Kumar B (1982) Pathogenic behaviour and varietal performance of Fusarium causing sugarcane wilt. Indian Sugar 32: 317-320.

42. Zummo N (1970) Unusual bending of sugarcane stalks associated with knifecut. Sugarcane Pathology News Letter 5: 10-11.

43. Kamal, Singh RP (1979) Knife cut disease of sugarcane in India. Sugarcane Pathologists' News Letter 23: 34.

44. Burgess LW (1981) Gneral ecology of Fusaria. Nelson PE, Toussoun TA, Cook RJ, (eds.). Fusarium, Diseases, Biology, and Taxonomy, Pennsylvania State University Press, University Park, Pennsylvania, USA 276-286.

45. Deacon JW (2006) Fungal biology. (4thedn), Wiley.

46. Barnes AC (1974) The sugarcane. $2^{\text {nd }}$ edition. Leonard Hill, Ltd., Londom.

47. Holliday P (1980) Fungus diseases of tropical crops. Courier Dover Publications

48. Bourne BA (1961) Fusarium sett or stem rot. In: Sugarcane disease of the world. Martin JP, Abbott EV, Hughes CG, (eds.). Elsevier, New York 186-202.

49. Patil AS, Singh H, Sharma SR, Rao GP (2007) Morphology and pathogenecity of isolates of Fusarium moniliformae causing Pokkah boeng of sugarcane in Maharastra, Ram RC, Singh A, (eds.). Microbial Diversity: Modern Trends Daya Publishers, New Delhi 234-263.

50. Mendes R, Pizziarani-Kleiner AA, Araujo WL, Raaijmakers JM (2007) Diversity of cultivated endophytic bacteria from sugarcane: genetic and biochemical characterization of Burkholderia cepacia complex isolates. Appl Environ Microbiol 73: 7259-7267. 